\title{
Implications of Zoom and Similar Apps on 'Flip-class' Outcome in the New Normal
}

\author{
Mohamed Buheji (Corresponding author) \\ Founder- International Institute of Inspiration Economy \\ E-mail: Buhejim@gmail.com \\ Dunya Ahmed \\ University of Bahrain \& International Institute of Inspiration Economy \\ E-mail: dr.dunya@hotmail.com
}

Received: July 10 20, 2020 Accepted: July 18, 2020 Published: July 20, 2020

doi:10.5296/ijld.v10i3.17374 URL: https://doi.org/10.5296/ijld.v10i3.17374

\begin{abstract}
The development of the New Normal in Post-COVID-19 has its implication on education. During just the first few months of the pandemic, many classes turned to be on Zoom, Google Class, etc. and many Universities activated their Blackboard or similar platforms. The classical education system has resisted this system change for many years, as they resisted more change in the mindset of how the classes should be delivered and managed.

This paper explores how the 'flip-class' and 'disruptive learning' can be part of the coming transformation towards preparing students more for the new normal required competency and enhance their life-purposefulness. The multidisciplinary, international researchers propose a hybrid model of Flip-class and Educational Social Network (ESN) could change the outcome of the courses intended learning to the better and prepare students for the unstable labour market.
\end{abstract}

Keywords: Educational Social Network (ESN), Zoom, Student Education, Flip-Class, Learning, Peer-to-Peer, Disruptive Education. New Normal, COVID-19

\section{Introduction}

The aim of this paper is to identify, analyse and describe how students can effectively lead the learning and the educational process through the Zoom similar apps where they experience flip-class and disruptive teaching methods. The paper presents elements of the authors teaching 
practices that have been used throughout the last five academic years. Such practices involve engaging students in the learning process, encouraging peers' observations and feedback, as well as developing the faculty to improve the way teaching is delivered. Chow et al. (2020), Rosenberg (2013), Falchikov (2001).

\section{Literature Review}

\subsection{Action Research Teaching}

Long before the COVID-19 pandemic, many faculties tried teaching methods that link between theory and practice, trying to bring different fields, ages, levels which cannot be divided in real life to be engaged during the process of learning. One of these teaching methods experienced by the author is the 'action research teaching' or 'applied teaching' which usually target to build a proper bridge of the subject under focus. In these types of teachings, the students are expected to learn by doing and practising and not by memorising. The overlap between teaching and engagement results along with the outreach activities enriches the student experience. Falchikov (2001), Kolb (1984).

\subsection{Multi-Disciplinary Teaching Approach}

There are different approaches that make certain universities have competitive differentiation; however, the most repeated differentiation comes from their 'multi-disciplined teaching approach'. That is happening between the colleges of Arts, Science, Technology and Business Schools. This is very similar to one of the models that were adopted in this study.

Segregation between disciplines is the norm in most of the universities around the world. Before the COVID-19, one would rarely see students taught from more than one teacher from different colleges. Few including the authors of this paper believed in multidisciplinary teaching, however, seen it to be difficult to arrange such teaching to sustainable and for many classes. With the ESN now students have more than two to three multidiscipline audience attending and commenting the class.

\subsection{Benefits of Education Social Networks in New Normal}

Education Social Networks (ESNs) as we call it are considered all the online modalities, platforms, apps that harness online engagement of large audience or population and are easily transformed on other types of social media, Budi et al. (2020). These ESNs open new opportunities to educate the students and enhance peer to peer discussion, besides be a reference for further learning or development. ESNs are mostly today going towards also open-access platforms, i.e. many of them have been now uploaded and can be accessed through youtube. Chow et al. (2020), Mpaata (2017).

Budi et al. (2020) COVID-19 pandemic spread over 210 countries has adversely impacted all areas of life, including education. Therefore, many universities started distance learning (DL) programs, or e-learning within the first few weeks from the reach of virus and the applying of social distancing or lockdown. The availability of the simple access to ESN has managed to close the infrastructure gap and made the difference in how the faculty manages the e-class. Many universities who did not have ready platforms licensed Zoom ${ }^{\circledR}$ account. Falchikov 
(2001).

\subsection{Introduction to Flip-Class}

Flip-class is a type of teaching style that enhances student amount engagement and active learning, while giving the faculty an opportunity to deal with mixed levels, student difficulties, and differentiated learning preferences during the in-class time, Busebaia and John (2020). Through the guidance of the faculty who would play the role of a mentor, the students would lead in the flip-class; they would present, discuss certain ideas, recommend certain online information, or induce online discussions, thus engaging other classmates and peer-to-peer learning. Budi et al. (2020), Chow et al. (2020), Davies et al. (2003). Hence, the flip-class is a total change from the traditional classroom teaching, where typically the teacher or the faculty would be the central disseminator of the information during the class period. In the flip-class, the teacher might delegate all the class to respond to certain questions, while only giving a small amount of guidance and feedback. In this type of class, the explanation of the course content is done by the students but with the mentorship of the teacher. Rosenberg (2013), Polding (2007).

While in the traditional model may be limited to activities in which students work independently or in small groups designed by the teacher and the control of the flow of the discussion and the pattern of information is also controlled by the teacher; in the flip-class is only an orchestra conductor. With the flipped-classroom, the learner-centred model dominates where the teacher explores the topics of what the students enjoy to learn and discuss and this increases the passion of learning and give students equal opportunities to excel on the subject of the discussion. Davies et al. (2003).

With a capacity of diversifying the 'content delivery' in different forms, or even invite a third party are used to deliver content, the introduction of an online alternative to the flip-class due to the COVID-19 pandemic help to further re-ignite the possibility the spread of the flipped-classrooms which could highly differentiate the outcomes of the intended programs and courses which are called for short the PILOs and the CILOs. The presence of online education with flipped-class might help to prepare the next generations of the new normal where more problem-finding thinking and collaboration are expected from them. Budi et al. (2020), Rosenberg (2013).

\subsection{Advantage of Flip-Class in the Times of Transformation}

Erdogan et al. (2018) discussed the advantages of the flipped-classroom model, which allow students to be prepared for the courses while increasing their motivation. With the flipped-class, the students could compensate for the missed class. In the meanwhile, the flip-class provides the teacher with the opportunity to observe the students learning cycle and enrich the time spent for a specific concept or activity.

In times of transformation, the flip-class could be one of the best feasible means to change the students' perception and more active to reflect on the experiences with the pandemic and their readiness for the new normal. 
In an era where positive attitudes and high response are highly expected, the development of the students' self-consciousness, while improving their capacity for problem-solving through effective team-work and communication would be very beneficial. And since the COVID-19 pandemic has brought with lots of stress and anxiety and especially for youth, the flip-class could be a very good alternative for deep dialogue between peer-to-peer review and mentors to student review. Mpaata (2017).

A recent study by Talan and Gulsecen (2019) compared the flipped-class with blended-learning and classical face-to-face learning, and found that the scores for the students' academic achievement and engagement were higher and the students were more satisfied with the flipped-classroom.

\subsection{Flip-class with Educational Social Network Apps}

Through the education social network (ESN) the flip-class became an easy reality for many teachers who resisted this change. Zoom and similar other e-learning and e-conferencing software all access and sharing the class from a variety of students, from a different nationality, different institutions, different backgrounds and interests which even thrive the class and open the students' perspectives about the subject matter of discussion and prepare them to real life. For example, an online case presentation that brings the audience that is interested in the case presented and not on the subject thrive the discussions. Rosenberg (2013), Bacal (2007).

\subsection{Role of ESN-Flip-class in Inspiring Self-Learning}

Self-learning and learning by doing have a more effective impact on students, according to the experiences of Dale (1969), as explained in 错误!未找到引用源。and 错误!未找到引用源。, which state that applied to teach, field trips, seeing real-life experiences, sharing the planning of the next step with students and modifying this together, have a greater impact on students. Kolb (1984).

This type of action research is linked to educational theories of teaching. Knowles (1984) created the Andragogy Theory Postulates, which are mainly related to involving adults in the teaching process (Falchikov 2001) by emphasising the following:

- Involve adults in planning and evaluation (self-concept and motivation to learn)

- Experience (including mistakes) provides the basis for learning activities (Experience)

- Immediate relevance to their job or personal life (readiness to learn).

- Adult learning is problem-centred rather than content-oriented (orientation to learning) = problem-solving.

\subsection{Requirement for ESN \& Speed of the Net}

One of the main challenges that would stay for many educational institutes, faculties and students is the availability and the speed of the internet network between the provider (the faculty) and the student. Regardless where is the provider the most important tool for him now is the accessibility to the ESN, whether the university defined, or through the new modalities. 
The most important is the ESN used should be suitable for mobile computing devices like smart-phones, tablets and laptops. However, the main worries about the using ESN online-teaching is that it might engender a form of behaviour commonly referred to as 'media multitasking'; which encourage the habit of the simultaneous use of multiple forms of media, or the use of media while performing another non-media activity.

There are clearly a gap in the literature for studies on the topic through both meta-data analysis after the COVID-19 on the level of students' performance outcome as part of the course intended learning outcome (called CILO's), after the end of the Spring 2020 semester.

\subsection{Student Convenience and Accessibility for Class Attendance}

Due to ease of accessing the classes from any place and any setting, regardless of the time, the accessibility is believed to increase also the reliability of the educational process. Taking the formula of inspiration economy which says:

Reliability $=P$ (Availability)

i.e. the more the educational sources are available to the student, which here means accessible, the more there is a probability of a reliable educational process. This accessibility increases the students' commitment among student in passionate attending, i.e. participating in deeper discussions. Bacal (2007).

This accessibility also increases the response time in sending the reports from both the students and faculty. In fact, many of the students used the real-time mode attachment in the ESN to sending in the reports, even before the time due. Some students even asked to attend with their friends' classes they did not take yet.

\section{Methodology}

A quantitative study focused on students were carried out to see the requirements of students, both attitudes and knowledge during the new normal. A questionnaire was set to measure the students' needs during the COVID-19 pandemic and then to compare it to what the flip-class could offer as a value-added advantage. The purpose was to explore and establish the importance of the flip-class even during the new normal times where online apps of ESN, including zoom, would be used to ensure social distancing. The outcome of the students' needs and what the 'hybrid flip-class-ESN' model relation are analysed. The results are then reflected in conclusions and where recommendations for the development of students centred teaching style that fits the new normal requirements.

The questionnaire gone through piloting stage, and then tested again, after being set electronically using google forms; with a consent form appended to it. The link of the questionnaire was sent to all international experts representing the International Inspiration Economy Project (IIEP) through emails, WhatsApp and other social media. The participants were encouraged to fill the complete survey due to its ease of filling. Thus, the link was forwarded to students apart from the first point of contact and so on. 
The survey contained 29 elements. The first part was about socio-demographic variables including age, gender, occupation, education and nationality. With two parts rated on a 5-point Likert scale range. First was measuring 13 elements regarding how they see the effect of COVID from strongly agree, Agree, Not Sure, Disagree, strongly disagree. While the other Likert scale measure 5 elements, about affected and changes to their lives, from high effect, to some extent, Natural, Not at all, Don't know.

\section{Data Analysis}

\subsection{General Demographics of the Data}

A data population of 141 international multidisciplinary students from Germany, Saudi Arabia, India, Croatia, Ghana, Jordan, France, United Kingdom, Poland, Russia, Tunisia, Ukraine, Albania, Malaysia, Egypt, Bosnia \& Herzegovina, Algeria, Kuwait; besides Bahrain were collected. After the demographics, two main questions on the google docs focused on the 'influence of COVID-19' and the 'realised change due to this pandemic' on students life were collected and analysed.

\subsection{How the Students believe that COVID-19 influenced their life?}

The analysis of this question was reflected in Figure (1) which shows that the majority of students (67\%) seen that the COVID-19 affected negatively on their psychological and social status and thus they feel unstable and unsecured with their future plans. However, still, $70 \%$ of these students believed that a challenge like COVID-19 pandemic, is a great growth driver for humans, including themselves. The interesting is that more than (84\%) of these students believe that the world economy will change dramatically in a few years because of the pandemic; therefore this population believed that new policies need to be developed for enhancing social and personal communications because of the pandemic experience.

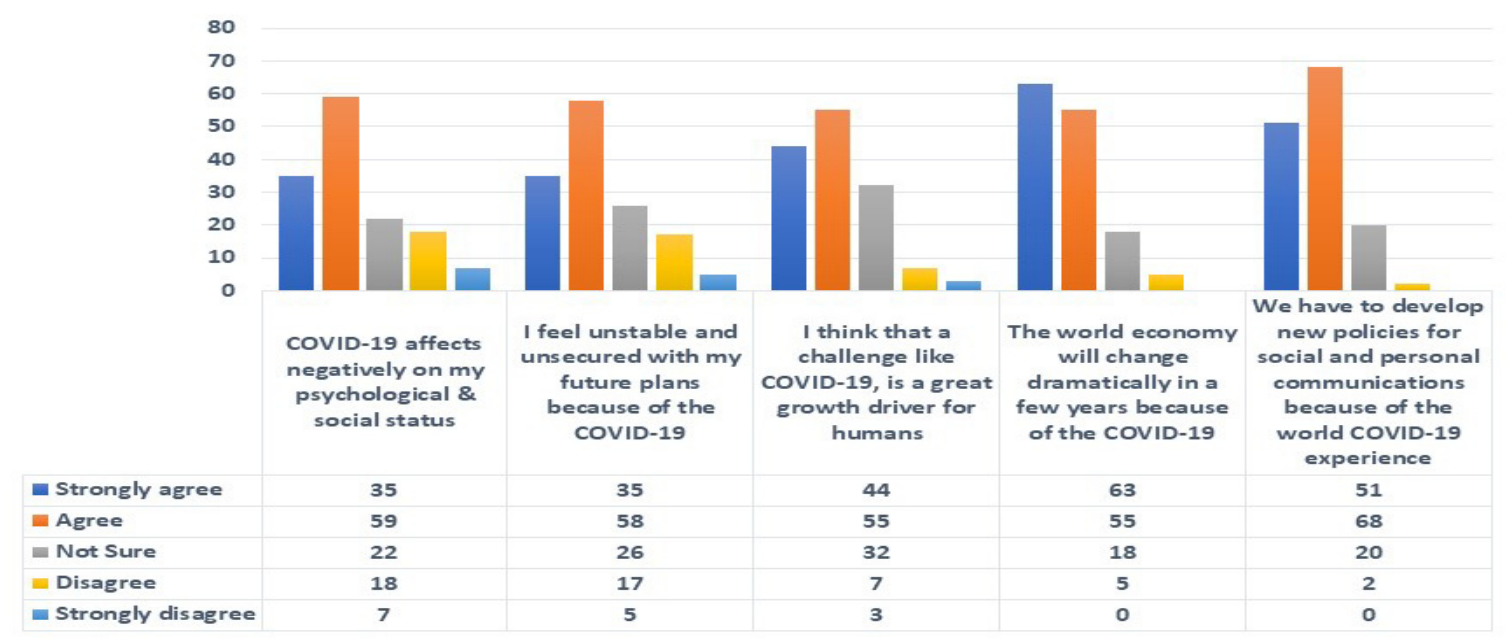

Figure 1. Shows how the COVID-19 Pandemic influenced the Students Life 


\subsection{The main changes of Students life Since the Pandemic Started}

When the students asked about the realised changes since the start of the pandemic the majority $(75 \%)$ believed that their mindset or (perceptions) about life and their life-purposes $(66 \%)$ started to change. The students believe that their readiness for other coming crises became much stronger (71\%). This is maybe because the majority started to see the world is small, and it needs more resilient communities. Figure (2) shows the answers for students life changes due to the pandemic.

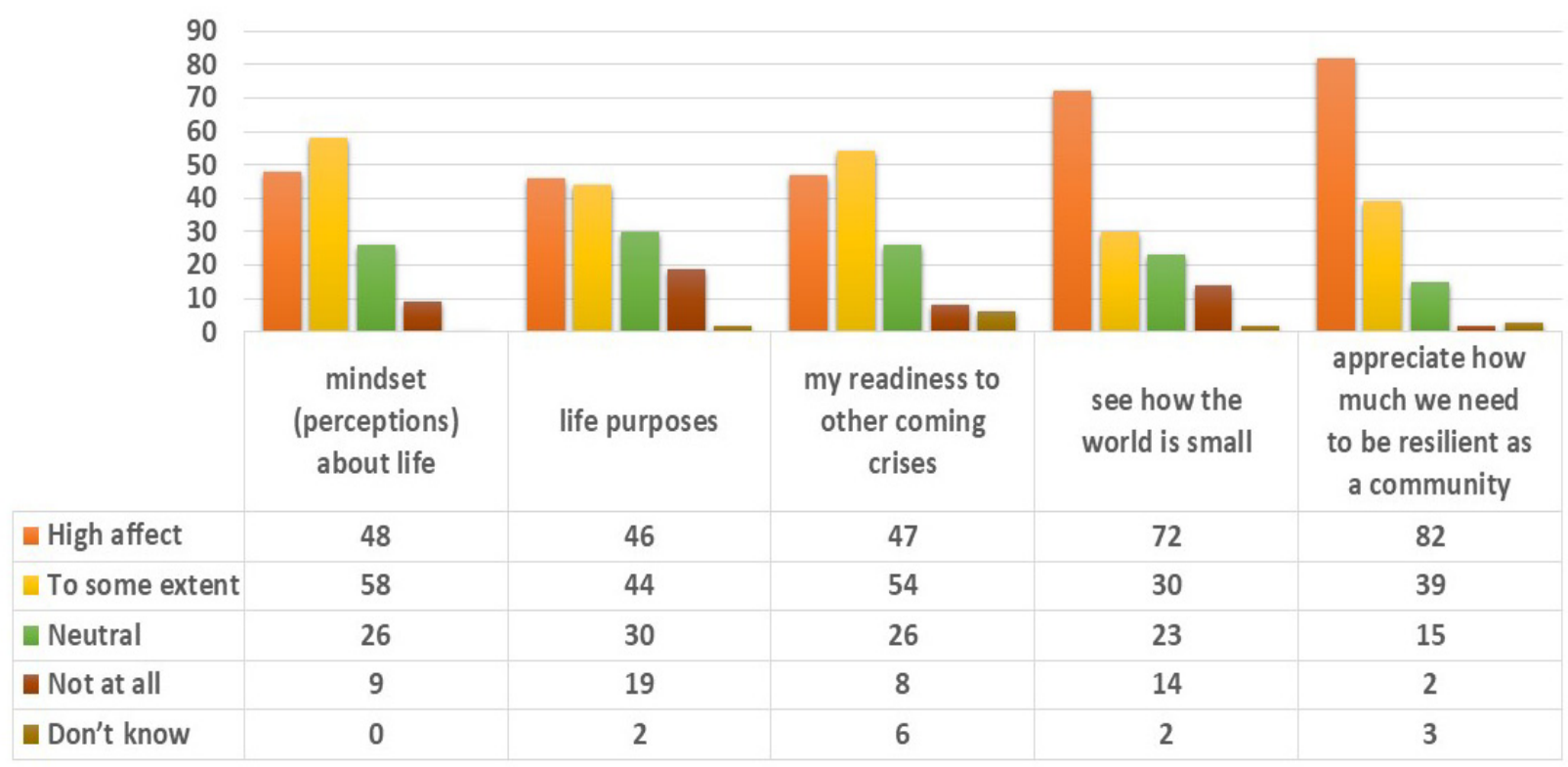

Figure 2. the Changes in students life due to the pandemic

\section{Discussion and Conclusion}

The COVID-19 pandemic forced most governments around the world to temporarily close educational institutions and any other productivity centres to contain the spread of the virus. At the peak of the pandemic, more than 1.5 billion learners, or over $90 \%$ of the world's student population from pre-primary to higher education, have seen their education disrupted and at times interrupted.

The ESN-Flip-class model tested by the international multi-disciplinary researchers and multi-institutions, multi-society, online cases give high reliability for the findings of this paper. ESN-online and flip-class hybrid model helps to trigger many students interests on the subject and enhance their capacity to get engaged in discussion more than classical teaching classroom. Polding (2007).

Despite the challenge of 'media multitasking' syndrome that might have occurred or would be occurred by the students on the long run and which needs more studies on the future, the 
positive outcome now emphasises the importance of this class mix approaches. Use of social media and online platforms as Zoom, YouTube, etc. brought a wider audience to the class and encouraged the students to thrive the class with lots of teaching and peer-to-peer learning collaboration. Chow et al. (2020), Polding (2007).

More studies are needed through both the meta-data analysis of what is published about the outcome of the online teaching, and the investigation of whether flip-class been used. Another opportunity coming is to initiate a global study, now after the COVID-19 pandemic, and in the new normal, about the level of students' performance outcome as part of the course intended learning outcome (called CILO's), after the end of the Spring 2020 semester. Then, other studies need to work on calibrating and alignment of the system and modes of delivery in the new normal, besides the academic tasks to enhance the learning outcomes, if shortages are found. Falchikov (2001).

This paper carries lots of implications for High Educational Institutes (HEIs) and especially at this moment where critical decision making has to be made about the re-opening or staying working from home, beside the teaching practices and styles in the new normal. The limitation of this paper is that it comes from the explored experience of the authors, and which due to the limitation of the scope of the paper, did not go into more comparative details that shows the difference of using ESN with other 'creative disruptive learning', or in comparison to the 'traditional teaching' educational techniques. However, this study contributes to researchers interested to see the development techniques for the students' outcome and their readiness to the new role in a labour market full of uncertainty and calls for further research in the field as the world trying to recover and start re-opening or overcoming the spillovers of the pandemic.

\section{References}

Bacal, R. (2007). Retention Rates - Hearing, Doing, Seeing - A Training and Learning Myth. Training and Development Resource Center, Retrieved 1/6/2020, from http://www.thetrainingworld.com/faq/mythlearningdoing.htm.

Busebaia, T. J. A., \& John, B. (2020) Can flipped-classroom enhance class engagement and academic performance among undergraduate pediatric nursing students? A mixed-methods study. RPTEL 15, 4. https://doi.org/10.1186/s41039-020-0124-1

Buheji, M., \& Ahmed, D. (2020). Planning for 'The New Normal' - Foresight and Management of the Possibilities of Socio-economic. Spillovers due to COVID-19 Pandemic, Business Management and Strategy, 11(1), 160-179. https://doi.org/10.5296/bms.v11i1.17044

Buheji, M., \& Buheji, A., (2020) Planning Competency in the New Normal- Employability Competency in Post- COVID-19 Pandemic. International Journal of Human Resource Studies, 10(2), 237-251. https://doi.org/10.5296/ijhrs.v10i2.17085

Buheji, M. (2019) Eliminating Poverty Through Educational Approaches-The Indian Experience. Review of European Studies, 11(3); 32-44. https://doi.org/10.5539/res.v11n3p32

Buheji, M. (2018). Handbook of Youth Economy. AuthorHouse, UK. 


\section{Macrothink}

International Journal of Learning and Development

ISSN 2164-4063

2020, Vol. 10, No. 3

Buheji, M. (2017). In Search of the Inspired Student-Measuring of Youth Inspiration in High School-A Youth Economy- Paper. American Journal of Industrial and Business Management, 7, 785-797. https://doi.org/10.4236/ajibm.2017.76056

Prihantono, A. (2020) Distance learning (DL) strategies to fight coronavirus (COVID-19) pandemic at higher education in Indonesia. International Journal of Psychosocial Rehabilitation, 24(7), 8777-8782.

Budi, H., Ludjen, J., Aula, A., Prathama, F., Maulan, R., Siswoyo, L., \& Prihantono, A. (2020) Distance learning (DL) strategies to fight coronavirus (COVID-19) pandemic at higher education in Indonesia. International Journal of Psychosocial Rehabilitation, 24(7), 2020, $8777-8782$.

Chow, R; Tan. N; Henry, T; Kanne, J; Sekhar, A (2020) Peer Learning Through Multi-Institutional Case Conferences: Abdominal and Cardiothoracic Radiology Experience. Academic Radiology. https://doi.org/10.1016/j.acra.2020.01.015

Davies, P. (2003). Practical Ideas for Enhancing Lectures. SEDA special No 13, Staff and Educational Development Association.

Erdogan, E., \& Akbaba, B. (2018) Should We Flip the Social Studies Classrooms? The Opinions of Social Studies Teacher Candidates on Flipped-Classroom. Journal of Education and Learning, 7 (1). https://doi.org/10.5539/jel.v7n1p116

Falchikov, N. (2001). Learning together: peer tutoring in higher education. London, RoutledgeFalmer.

Kolb, D. A. (1984). Experiential learning: experience as the source of learning and development. Englewood Cliffs; London, Prentice-Hall.

Mpaata, A. (2017) Youth Personality Development and the Ultimate Character: The Neglected Role of Educators. International Journal of Youth Economy, 1(1), 105-118. https://doi.org/10.18576/ijye/010107

Polding, L. (2007). Leading Change - Integrating E-Learning into an Existing Course. Legal Information Management, 7(01), 59-63. https://doi.org/10.1017/S1472669606001174

Rosenberg, T. (2013). In 'Flipped' Classrooms, a Method for Mastery. New York Times.

Talan, T., \& Gulsecen, S. (2019). The Effect of a Flipped-Classroom on Students' Achievements, Academic Engagement and Satisfaction Levels. Turkish Online Journal of Distance Education, 20(4). https://doi.org/10.17718/tojde.640503 


\section{Macrothink}

International Journal of Learning and Development

ISSN 2164-4063 2020, Vol. 10, No. 3

\section{Copyright Disclaimer}

Copyright for this article is retained by the author(s), with first publication rights granted to the journal.

This is an open-access article distributed under the terms and conditions of the Creative Commons Attribution license (http://creativecommons.org/licenses/by/4.0/). 